\title{
Morocco's Rock Art: Age and Meaning
}

\section{Susan Searight}

42 Rue Franceville, Casablanca 20410, Morocco; E-Mail: searightsusan@ yahoo.co.uk.

Received: 28 January 2013; in revised form: 5 February 2013 / Accepted: 6 February 2013 / Published: 8 February 2013

\begin{abstract}
The general distribution of the rock art sites in Morocco is indicated in this report. The vast majority are situated in southern Morocco, in the region of the River Draa and further south. One important exception is the High Atlas mountain range. The location of these sites is shown to be fairly standardised. Four different groups of engravings are identified, based on technique and theme. In the absence of any direct dating of the engravings, these groups can only be placed in a relative chronological order, using dates known for climatic conditions and the introduction of animals or objects. A problem concerns the reliability of these 'known' dates, often based on extrapolation from dated information from neighbouring countries. Two recent excavations close to rock art sites have yielded $\mathrm{C} 14$ dates for population presence in the area without advancing knowledge on the date of the rock art. The reason for sites' geographical situation in the landscape can probably be surmised reasonably accurately, but the interpretation of this art remains largely a matter of speculation and intelligent guesswork. Current projects aimed to advance knowledge of the age of the art are described.
\end{abstract}

Keywords: Morocco, rock art, chronology, research, meaning

\section{Introduction}

Morocco, at the western tip of North Africa (Figure 1), is generally considered as the distant, and rather impoverished, offshoot of the vast and rich sphere of Saharan rock art, a backwater or end product lacking in originality and poor in imagery. In fact, this is a very simplistic view of Moroccan rock art. With well over 300 engraved sites containing a diversity of themes unparalleled elsewhere in 
northern Africa, Moroccan rock art adds an essential chapter to our knowledge of the region's prehistoric and protohistoric populations.

Figure 1. Map of Morocco

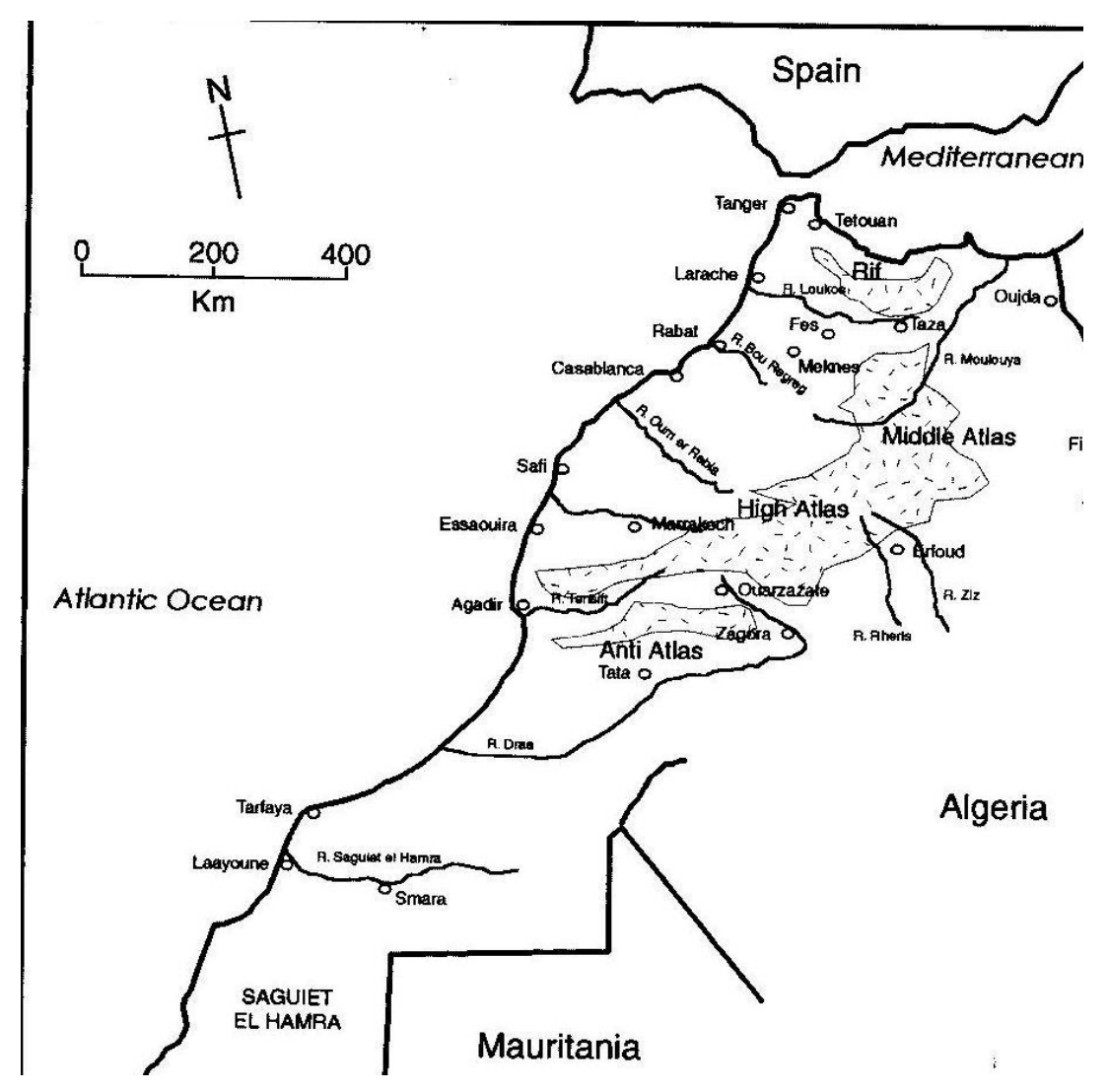

To be sure, Moroccan art is not to be compared to that of the Libyan Messak and the Akakus, themselves outstanding sources of information on the way of life of the early inhabitants. Nor do its 30 or so sites with painted images come up to those of the Tassili n'Ajer, Libya or southern Egypt.

However, the High Atlas Mountains contain dozens of sites characterised by engravings of metal weapons, quite unique in North Africa, and in southern, pre-Saharan Morocco, sites with small polished engravings of Tazina style far outnumber those in the Algerian Saharan Atlas, where this style was first described.

\section{Distribution and location}

Unlike the cave art of France and Spain, Moroccan sites are with few exceptions in the open air and clearly visible. Even the paintings in the rock shelters are in no way hidden or difficult to access. Looking at this distribution, Simoneau [1] defined three geographically privileged landscapes: the High Atlas Mountains, the southern foothills of the Anti-Atlas and the pre-Saharan hydrographical basins. More simply, one can divide Morocco into two contrasting zones: one the High Atlas, the other south of this range, a country of oases and deserts 
For the most part, the engravings in southern Morocco are on low sandstone crests close to a river, overlooking what was at one time pasture land. They were made on free-standing blocks or slightly inclined strata, occasionally also on the vertical faces of rocky escarpments. In the High Atlas sectors of the Oukaimeden and, Yagour Plateaus and the Jbel Rat, south of Marrakech, the engravers used preferentially the sloping sandstone slabs that cut up the rich mountain pastures. These rich grazing grounds, at 2,000 metres and over, are today open in the summer to the herds of local cattle and sheep and were certainly so in the past. .

Four main groups of engravings can be distinguished, based on technique and theme. One group, is found on sites east and south of the River Draa before appearing again far to the south, around Smara, in the Saguiet el Hamra (Western Sahara), and contains a majority of wild animals and a few obviously domesticated bovids in the polished Tazina style (Figure 2).

Figure 2. Tazina style animals from Ait Ouazig, River Draa valley, south-east of Ouarzazate.

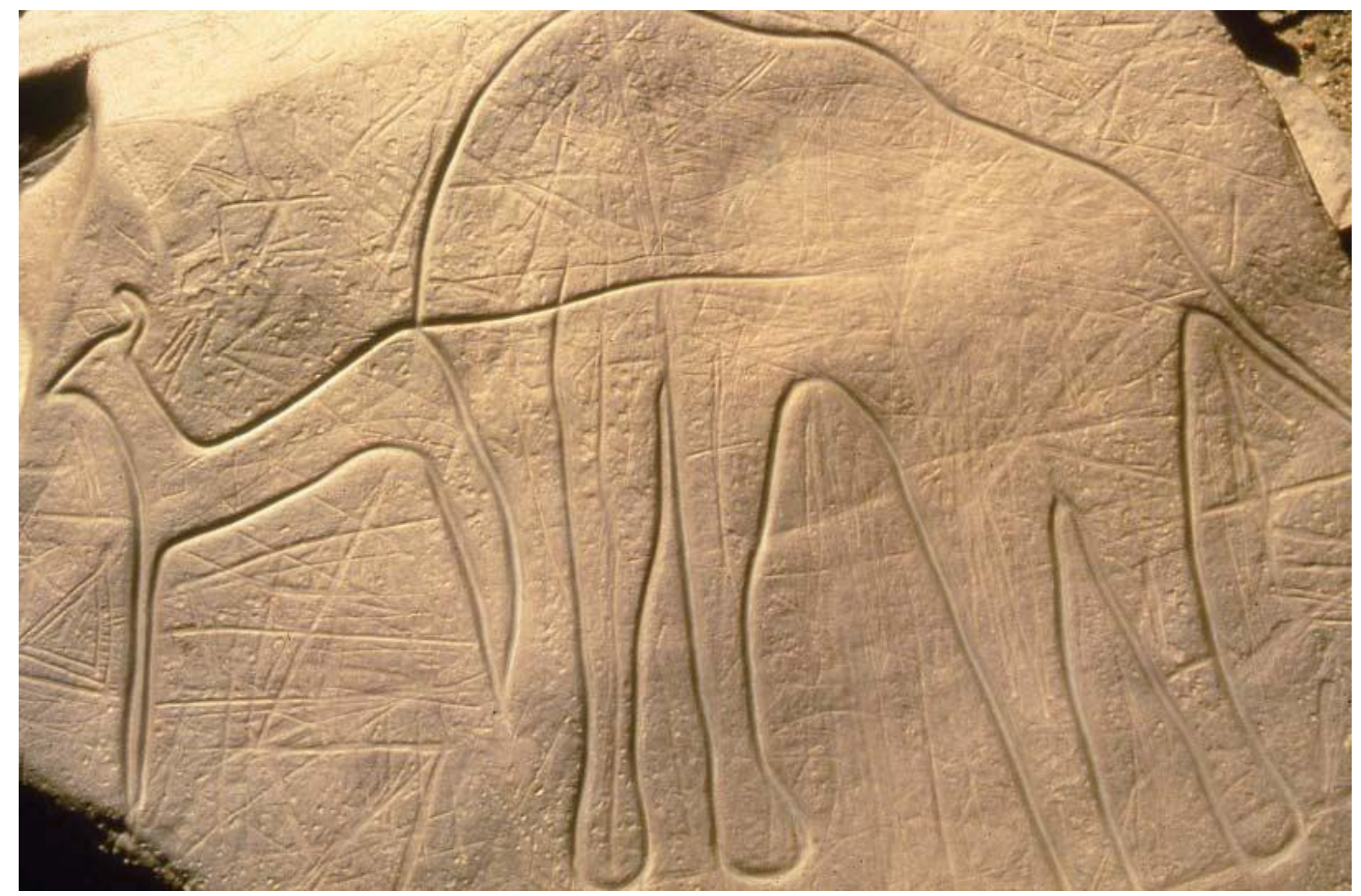

A second group, called the Pecked Cattle group by Searight [2] reverses both technique and content by concentrating on pecked domestic cattle with a few wild animals (Figure 3). 
Figure 3. Example of pecked cattle group from Adrar n'Metgourine, west of Tata, south Morocco.

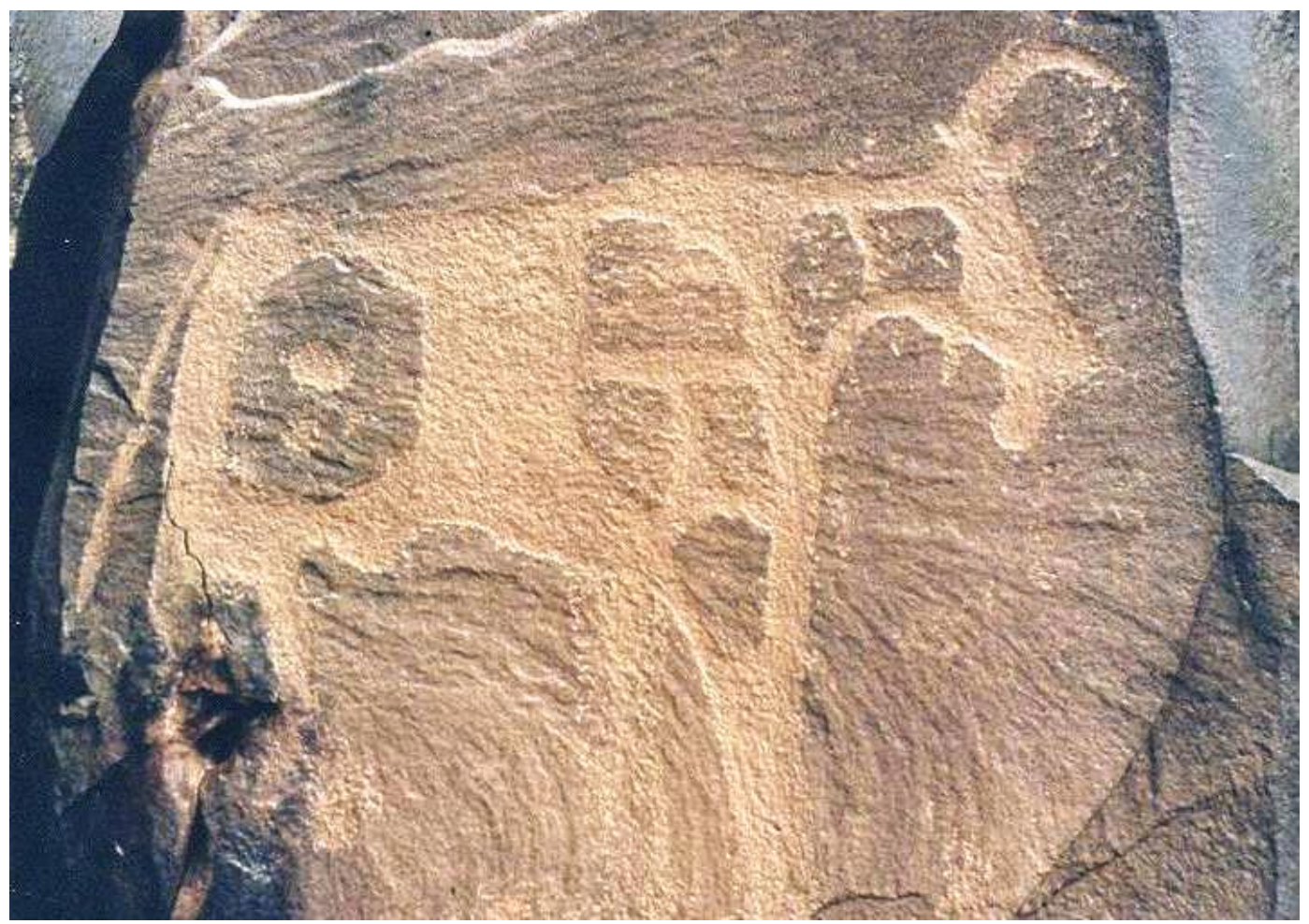

Still in southern Morocco, well represented in a site on the west bank of the River Draa, a third group is totally different: small, pecked 'stick-figures' of horsemen and foot-soldiers are shown fighting or hunting lions, leopard and Barbary sheep (Figure 4).

Figure 4. Fighting scene from Foum Ech Chenna, north of Zagora, River Draa valley.

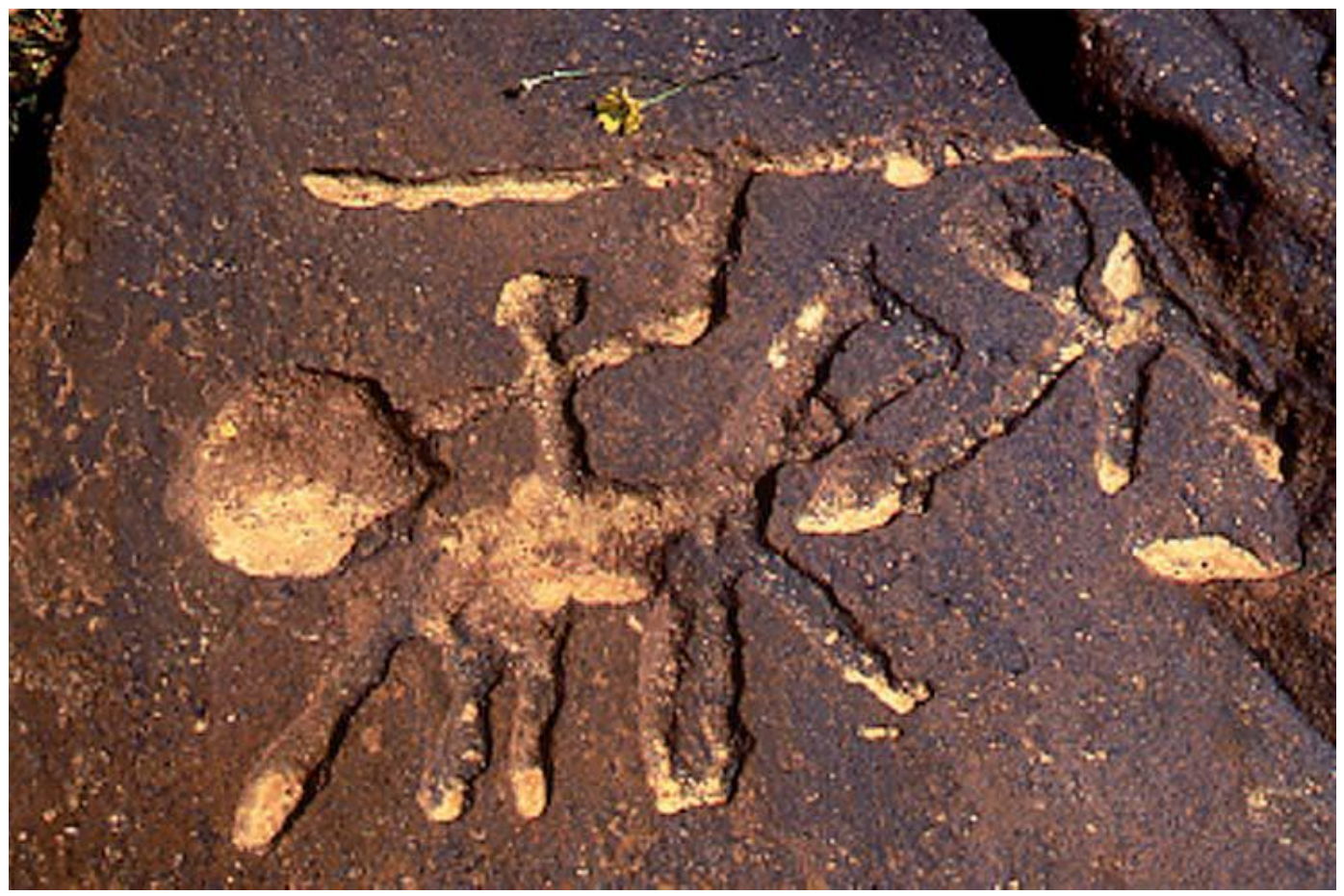


The fourth group, confined to the High Atlas (with one or two inevitable exceptions) is again quite different, with pecked (sometimes also then polished) daggers and halberds, full-side human figures often surrounded by weapons, as well as domestic cattle and a few wild animals (often lions or leopards) (Figure 5).

Figure 5. Halberds engraved on the Yagour Plateau, High Atlas.

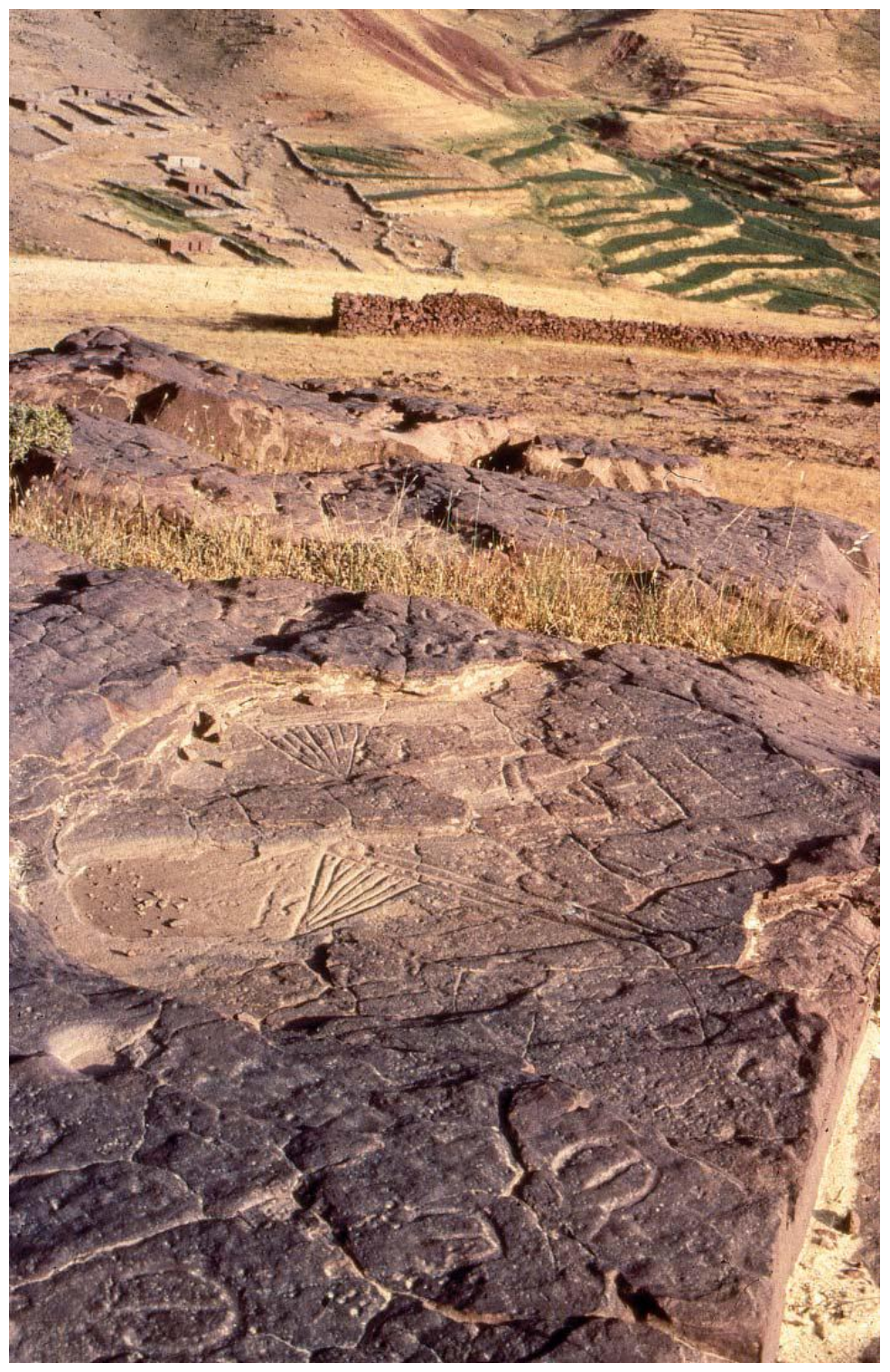

\section{Time scale}

The problem of course is putting a date to these four groups in the absence of any direct dating. They can be placed in a relative chronological order, using climatic conditions, dated occupation of not too distant, non-iconographic sites, the appearance of animals or objects for which dates are known. Unfortunately, dates for the appearance of real objects found in excavations (weapons or animal bones, for instance) come from sites often many hundreds or thousands of kilometres away and cannot take into account the time-lag in their appearance in an engraved form in Morocco. This question was taken 
up by Chenorkian [3]: was a dagger quickly the object of an engraving because it was a novelty, or did it take some time to be incorporated into the local iconography? The same remark could be said of such things as chariots or camels.

Researchers have found no difficulty in following the generally accepted North African sequence for the southern Moroccan rock art, based essentially on the images represented: Naturalistic Bubaline, Bovidian, Cabellin and Cameline. In other words: wild animals (characterised by the giant buffalo, bubalus antiquus), domestic cattle, then horses, then dromedaries (here called 'camels'). In this connection, the Naturalistic Bubaline period is not clearly established in Morocco, the name 'Bovidian' is not appropriate for Morocco and should be reserved for the cattle images of the Sahara (Muzzolini) [4] and replaced, for example, by that of 'Pecked Cattle' (Searight) [2] and the horse/camel period is labelled Libyco-Berber. In addition to this classic series, more modern engraved sites exist, depicting Berber jewellery and Arab daggers. Into this schema has to be fitted images of chariots, present on many sites throughout the country, and inscriptions in the old Libyan alphabet (the age of which is uncertain).

The engravings of the High Atlas Mountains add a totally different aspect to Moroccan rock art and are slotted into the above sequence for southern Morocco, more or less according to whether the researcher considers the southern Moroccan sites to be 'old' or 'young'.

\section{Approaches to the question of chronology}

As yet, no firm scientific dating is available for any Moroccan engravings. However, in the context of the European Commission's Desert Patina programme on the formation of patina, detailed field and laboratory studies on engravings on a pre-Saharan site have produced the information that the majority were made during a Holocene wet period (Boizumault et al., forthcoming) [5], most probably sometime during the Neolithic Humid, after 4500 bc. But this scarcely provides an answer to the question of exactly when they were carried out, since other indicators already pointed in this direction.

Another approach for dating the rock art and its environment is being undertaken in south-west Morocco. In 2008, a convention concerning the painted rock art shelters near Tan-Tan (1) was signed between France and Morocco. It aims to undertake a complete inventory, 3D reproduction and study of the paintings, to date them by means of micro-sampling and carry out field research to recover pertinent archaeological information. The shelters are revealing themes, such as archers, not as yet seen elsewhere in Morocco, which may provide useful chronological information.

In the High Atlas a comparative dating approach has been applied to halberds and daggers engraved on the sites of Oukaimeden and the Yagour Plateau. On typological grounds, some of the halberds and the most simple daggers have been likened to real weapons found in the course of excavations of the Early Bronze Age sites of El Argar and Carapatas in southern Spain, the dates of which lay around the middle of the $2^{\text {nd }}$ millennium bc. The rest were of $1^{\text {st }}$ millennium bc age, with indigenous models becoming current (Chenorkian) [6].The Iberian Early Bronze age dates have been recently revised, with calibrated dates of 2250 - 1550 BC (Lull et al, 2005: 248) [7]. This could seriously age the period when the first daggers and halberds were being produced in the High Atlas, and this revision would also affect the age of links between the High Atlas and southern Moroccan sites. The problem of the time-lag between the date of the real weapons and their engraved versions is discussed above. 
Nevertheless it seems safe to date appearance of the oldest High Atlas engravings to somewhere within this rather long period.

A recent attempt to link the Oukaimeden engravings with the people who made them was carried out as part of the European Commission's Desert Patina programme. Seven trial trenches were opened, one of them directly below a 3-metre long frieze composed of three elephants, a rhinoceros, two 'praying' human figures, two lines of letters in the old Libyan alphabet and a lion. At a depth of just under one metre below the present surface (and the base of the engraved rock) a small, prepared hearth gave a C14 date of between 900 and 750 cal.BC (El Graoui et al, 2008) [8]. None of the images provide a clue as to their date of execution, except for the inscription. Despite controversy, this alphabet is only attested from the $6^{\text {th }}$ century BC (Aghali-Zakara, 1997:2) [9]. It is unlikely that the frieze existed before the hearth was in use, in which case it is tempting but purely speculative to imagine that the hearth-makers engraved the frieze, thereby pushing back the date of the inscription (unless it was added much later).

Thermoluminescence dating on three pottery sherds with red ochre pigment from an excavation below a ledge containing red ochre paintings at Toulkine, in the High Atlas foothills south of Marrakech, came up with dates from 2120 to 2420 BC (Ousmoi) [10]. Unluckily, the paintings are made up of macaronis, smears and wavy lines, unrelated to any other known painted sites in Morocco. More usefully, a particular type of flint point from this site has also been found on the Oukaimeden plateau, indicating that the Toulkine people were up there hunting - but nothing proves they were also engraving.

\section{Interpretation}

Can today's researchers really claim to be able to interpret the images of the past? Rock art is widely considered a medium of communication, an unspoken language (Davis 1984: 7) [11], or exchanges within the framework of a social organisation. Amongst other possibilities, the information exchanged by means of paintings or engravings could identify the sender, furnish knowledge on the environment (presence of water supplies, food or predators), indicate traditional transhumance routes or territorial rights.

Whatever the message, the information was not placed haphazardly in the landscape: it was put where the makers intended it to be.

According to the purpose of the message, it could have been addressed to the members of the tribe using them, to neighbours (friendly or otherwise) or known enemies. For internal use, they could have served as warnings (for instance, a man confronted by a menacing lion in a southern site), or history lessons (fighting and leopard hunting in the High Atlas and in a River Draa valley site); for neighbouring tribes, the round engraved shields in the High Atlas could have indicated the lands of local chiefs'; the life size humans assailed by weapons engraved in the High Atlas may commemorate a battle hero or a vanquished enemy; animals engraved on the low sandstone ridges in south Morocco were possibly signs of territorial ownership.

As many of the images in Moroccan rock art are clearly identifiable, it is possible to ascribe a primary meaning to them. The image is clearly a dagger, an antelope, an elephant, a fighting scene. 
Also equally clear is that most, if not all, have a secondary meaning, limited in extension, whose symbolic sense depends on factors outside our present knowledge,

\section{Conclusion}

Great strides forward have been taken in recent years to define the environment of past rock art manifestations. Much remains to be done. The use of new dating techniques, local environmental studies and more excavations in zones rich in rock art will certainly advance knowledge on the age of these manifestations. At the moment, however, the interpretation of this art continues to be risky. Attempts can be made to delve into the symbolism underlying the simple image but this too is a difficult task and tends to depend on the researcher's own cultural background.

\section{Note}

(1) The first painted shelter was initially visited in November 2001 (Searight \& Martinet, 20012002) [12] but the current research is already providing new data on the region, as several other painted shelters have been discovered since the first one was published.

\section{References}

1. Simoneau, A. Catalogue des sites rupestres du sud marocain. Ministère d'État chargé des Affaires Culturelles, Rabat, 1977.

2. Searight, S. The Prehistoric Rock Art of Morocco. A Study of its extension, environment and meaning. BAR International Series 1310, 2004

3. Chenorkian, R. Art rupestre des âges des métaux“ In : Ed. Mohen, J.P. Le Temps de la Préhistoire, 1989, pp. 188-192

4. Muzzolini, A. Les images rupestres du Sahara. Toulouse, 1995.

5. Boizumault, M.; El Graoui, M.; Searight-Martinet, S.; Ney, C.; Schvoerer, M. Patines et cortex de météorisation de grès du site rupestre d'Oum La Leg (Anti-Atlas, Maroc), in press.

6. Chenorkian, R. Les armes métalliques dans l'Art Protohistorique de l'Occident méditerranéen. CNRS, 1988.

7. Lull, V.; Mico, R.; Rihuete, C.; Risch, R. 2005. Property Relations in the Bronze Age of Southwestern Europe: an Archaeological Analysis of Infant Burials from El Argar (Almeria, Spain). Proc. Prehis. Soc. 2005, 71, 247-268.

8. El Graoui, M.; Alifriqui, M.; Junger, H.; Nahid, A.; Searight-Martinet, S. Recherches d'indices chronologiques sur le passage des graveurs de rochers de l'Oukaimeden (Haut Atlas, Maroc). Sahara 2008, 19, 105-108

9. Aghali-Zakara, M. Alphabets Libyco-berbères et informatique. Epigraphie Libyco-Berbère. La Lettre du RILB, 3 :2, 1997.

10. Ousmoi, M. Application de la datation par thermoluminescence au Néolithique marocain. Unpublished doctoral thesis, Blaise Pascal University, Clermont II, France, 1989. 
11. Davis, W. Representation and Knowledge in the prehistoric rock art of Africa. Afr. Archaeol. Rev. 1984, 2, 7-35.

12. Searight, S.; Martinet, G. Peintures rupestres d'un nouveau genre dans le Sud marocain. Sahara 2001, 13, 115-119.

(C) 2013 by the authors; licensee MDPI, Basel, Switzerland. This article is an open access article distributed under the terms and conditions of the Creative Commons Attribution license (http://creativecommons.org/licenses/by/3.0/). 